\title{
THE EFFECT OF A-LIPOIC ACID ON THE FUNCTIONAL STATE OF PERIPHERAL NERVE FIBERS IN POLYNEUROPATHY OF THE LOWER EXTREMITIES IN PATIENTS WITH CHRONIC HEMOBLASTOSIS
}

DOI: 10.36740/WLek202009217

\author{
Oleksandra 0. Piddubna, Nataliya V. Lytvynenko, Anzhelina M. Krivchun, Kateryna A. Taryanyk \\ UKRAINIAN MEDICAL STOMATOLOGICAL ACADEMY, POLTAVA, UKRAINE
}

\begin{abstract}
The aim: To evaluate the effectiveness of the appointment of a- lipoic acid for correcting electroneuromyographyc indicators polyneuropathy of the lower extremities in patients with hemoblastosis.

Materials and methods: The study included 77 patients from hematology department of Poltava Regional Hospital, who were divided into 3 groups according to the underlying disease: Group 1 - patients with chronic myeloid leukemia (CML) $(n=26)$ groups and 2 - patients with chronic lymphocytic leukemia (CLL) ( $n=27$ ), group 3 - patients with multiple myeloma $(M M)(n=24)$. For the examined patients were taken electroneuromyographyc researches of distal lower extremities by measuring the following parameters: the amplitude of the M-response from short extensors nerves of the fingers (MEDB) and abductor of the big toe (MAH) and the rate of excitation the spread of short extensors nerve of the fingers (VEDB), thumb abductor (VAH), superficial shallow (VSF) and calf (VC) nerves on both sides (sin/dex) before and after administration of a- lipoic acid. Results: ENMG examination of the peripheral nerves of the lower extremities in patients with CML and CLL revealed a slight decrease in M-responses at normal values of the rate of conduction of excitation through sensory and motor fibers. In patients with $\mathrm{MM}$, multiple lesions of peripheral nerve fibers of the lower extremities were detected, which is represented by a decrease in the M-response and the rate of excitation through sensory fibers and indicates deeper lesions, namely the axial cylinder, which requires longer treatment. The difference in the dynamics of the studied indicators indicates a different degree of PNP. Administration of a-lipoic acid increased the M-response rate and the rate of excitation of motor fibers in all groups of patients. The rate of excitation through sensory fibers was improved in patients with CLL and MM. Following the use of a-lipoic acid in the complex treatment of patients with MM ENMG, the signs of peripheral nerve fiber damage in the lower extremities were worse due to the severe initial condition, but reached a medium level. The positive effect of a-lipoic acid can be caused by a decrease in oxidative stress and endothelial dysfunction in nerve vessels, and, as a consequence, an improvement in the trophism and functional state of nerve fibers.

Conclusions: ENMG signs of defeat of PNP of the lower extremities are more expressed at MM. The appointment of a-lipoic acid in the complex treatment of PNP in patients with chronic hemoblastosis improves the functional state of the peripheral nerve fibers of the lower extremities and may be a component of pathogenetic therapy.
\end{abstract}

KEY WORDS: Chronic hemoblastosis, peripheral nervous system, polyneuropathy, electroneuromyographic, a-lipoic acid

Wiad Lek. 2020;73(9 p. II):1990-1994

\section{INTRODUCTION}

Hemoblastosis is the collective name of neoplastic diseases of the blood system, which are malignant neoplasms from cells of hematopoietic and lymphatic tissues with involvement in the process of a number of organs and body systems. They account for more than $1 / 3$ of all tumors in the population and are the leading cause of death among all diseases of the blood system [1-8]. Neurological disorders in patients with hematologic diseases (PHD) are classified as the secondary lesions of the nervous system (NS). Attachment of neurological symptoms to the main symptoms of hemoblastosis significantly increases the severity of the patients' condition and affects the outcome of treatment $[9,10]$. In recent years, in the process of PHD monitoring, there has been an increase in the frequency of peripheral nervous system (PNS) lesions, not only during specific treatment, but also at the stage of diagnosis. Polyneuropathy (PNP) is the most common lesion of PNS. Depending on the pathogenesis, peripheral neuropathies in diseases of the blood system can be divided into 4 groups: specific metabolic disorders in the nervous system; compression of nerves; infiltration of peripheral nerves by mast cells; toxic medicinal polyneuropathies [11]. Post-chemotherapy polyneuropathy (HTPNP) is a specific systemic manifestation of neurotoxicity that affects both the quality of life of cancer patients and the possibility of anticancer treatment. According to a number of literature sources, chemotherapy-induced polyneuropathy occupies the first place in the structure of PNS lesions and is on average $40-60 \%$ [12-14]. Therefore, in chronic hemoblastoses ( $\mathrm{hml}, \mathrm{hlm}, \mathrm{mm}$ ), the clinical manifestations of PNP from the very beginning of the disease are so variable that in most cases for the diagnosis of PNP, electroneuromyographic (ENMG) research is crucial diagnostic value, as noted by many authors and diagnoses peripheral nerves, which allows evaluating their functional characteristics [15-18]. According to the results of clinical studies at ENMG examination of patients with MM, it was found a decrease in the amplitude of muscle responses (M-responses) in the stimulation of the 

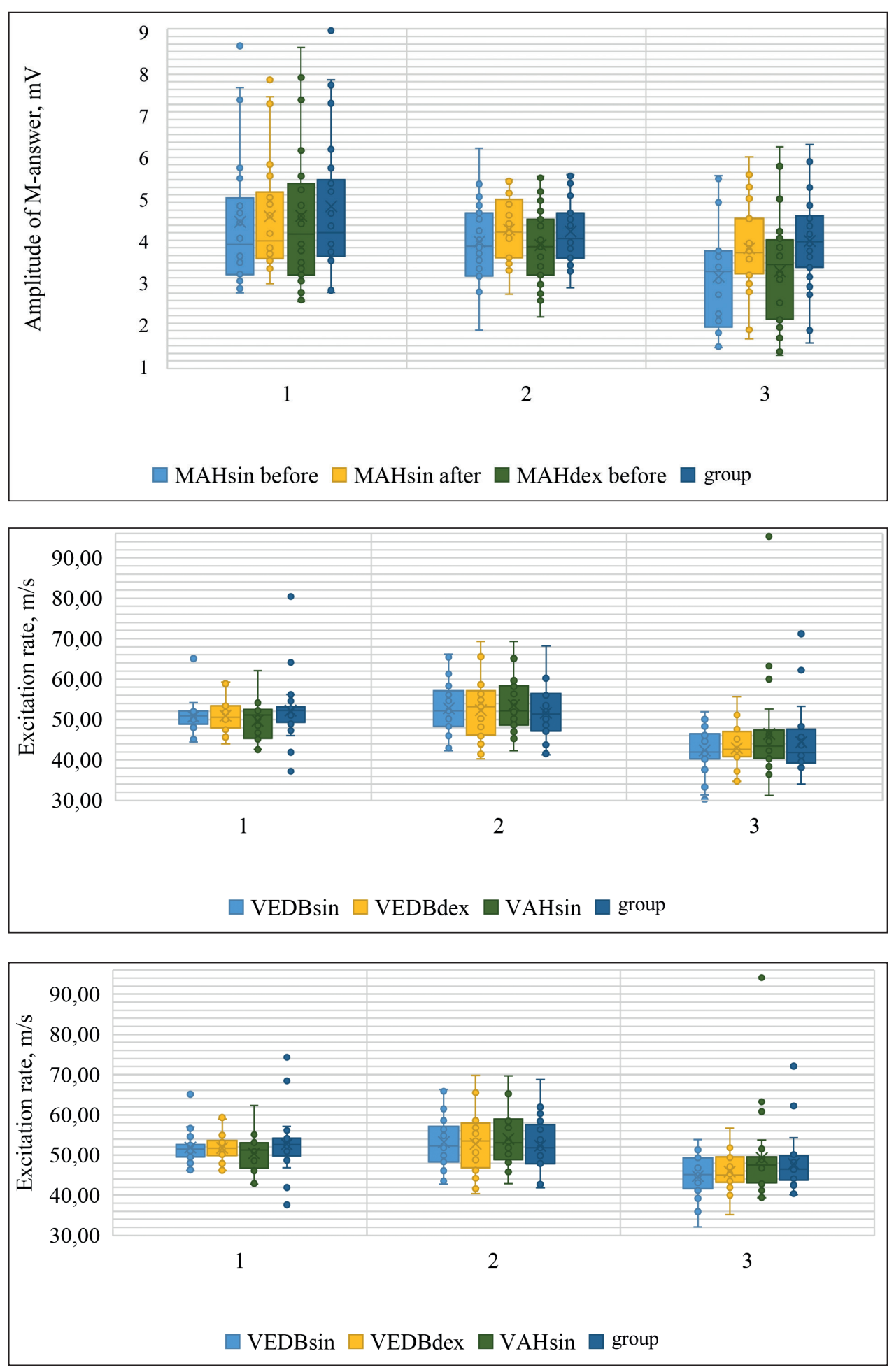

Fig 1. The amplitude of the M-response before and after the treatment with alipoic acid from the nerve of the muscle, which takes away the thumb of the foot.

Fig 2. The speed of excitation on motor fibers before treatment with $a$ - lipoic acid.

Fig 3. The speed of excitation by motor fibers after treatment with $a$-lipoic acid. tibial nerves, the action potential of the calf nerves, the amplitude of the evoked cutaneous sympathetic potential from the feet, and the increase in sympathetic volume. potential, reduction of the speed of propagation of excitation on the motor and sensory fibers of the tibial and calf nerves. Thus, according to ENMG, signs of motor-sensory-vegetative PNP were detected in the legs of the axon-demyelinating type, mainly axonal with secondary demyelination [19]. It should be noted that to date, there is no conclusive data on ENMG examination of patients with CML and CLL. Thus, the problem of timely diagnosis of the diagnosis and treatment of CTPD in chronic hemoblastoses is extremely important for improving the quality of life of patients.

\section{THE AIM}

The aim was to evaluate the effectiveness of the appointment of $\alpha$ - lipoic acid for correcting electroneuromyographyc indicators polyneuropathy of the lower extremities in patients with hemoblastosis. 

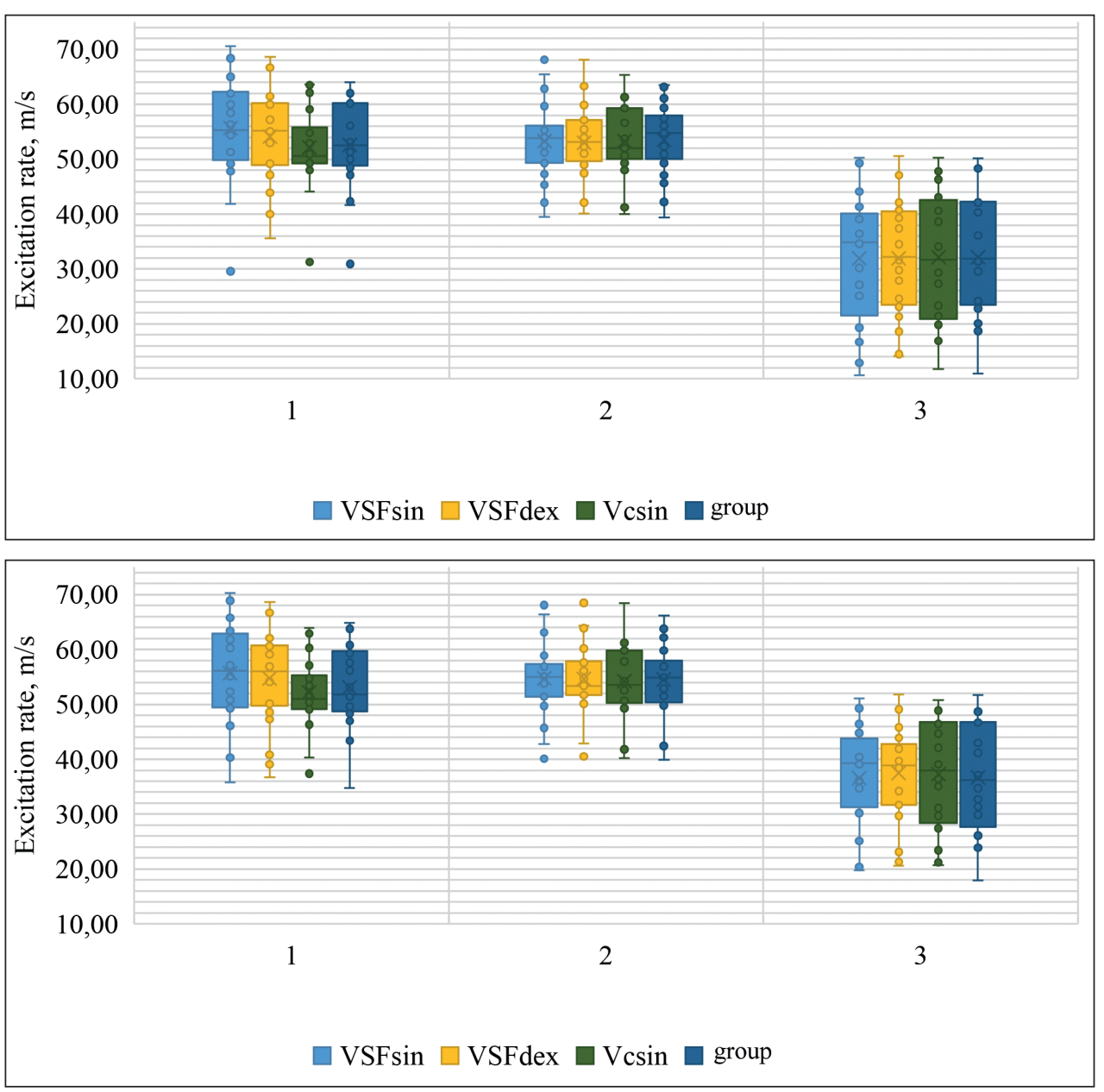

Fig 4. The rate of excitation of sensory fibers before treatment with a- lipoic acid.
Fig 5. The speed of excitation by sensory fibers after treatment with a-lipoic acid.

\section{MATERIALS AND METHODS}

The study included 77 patients from hematology department of Poltava Regional Hospital, who were divided into 3 groups according to the underlying disease: Group 1 - patients with chronic myeloid leukemia $(\mathrm{CML})(\mathrm{n}=$ 26) groups and 2 - patients with chronic lymphocytic leukemia (CLL) $(\mathrm{n}=27)$, group 3 - patients with multiple myeloma $(M M)(n=24)$. Inclusion criteria: the presence of CML, CLL, MM; at least 1 course of chemotherapy (CT); age more than 18 years. Exclusion criteria: other hematologic diseases; undergoing the first course of chemotherapy; age under 18years; increased sensitivity to $\alpha$ - lipoic acid preparations. All patients were treated according to standard protocols due to the underlying disease and received $600 \mathrm{mg}$ of $\alpha$ - lipoic acid twice daily for 6 months. Patients were given written informed consent to conduct the research following the recommendations of the ethics committee questions of biomedical research and the Helsinki Declaration.

For the examined patients were taken electroneuromyographyc researches of distal lower extremities by measuring the following parameters: the amplitude of the $M$-response from short extensors nerves of the fingers (MEDB) and abductor of the big toe (MAH) and the rate of excitation the spread of short extensors nerve of the fingers (VEDB), thumb abductor (VAH), superficial shallow (VSF) and calf (VC) nerves on both sides ( $\sin /$ dex) before and after administration of $\alpha$ - lipoic acid. Statistical analysis was performed using IBM SPSS Statistics 23.0. The Shapiro-Wilk test was used to evaluate the normality of quantitative distribution. The results are presented as mean values $(\mathrm{M})$ and root mean square deviations $(\sigma)$ or median $(\mathrm{Me})$ and interquartile $(25 \%$ - 75\%) span ( Q1-Q3) depending on the distribution. For data that is subject to the normal distribution used single-factor analysis of variance ANOVA with Bonferroni correction. If the distribution was different from the normal, the Crackel-Wallis test was used, followed by a posteriori analysis by the Dan criterion. Comparisons of pre- and post-treatment data were performed using Student's t-test for related samples in the case of normal distribution and Wilcoxon's criterion for distribution other than normal. The results were considered statistically significant at $\mathrm{p}<0.05$ and posterior comparisons at $\mathrm{p}<0.017$.

\section{RESULTS AND DISCUSSION}

In group 1 (mean age $54 \pm 15.76$ ), the duration of the disease was 1.5 (1-4) years and the number of courses of CT was 1 (1-2). In group 2 (mean age $59.96 \pm 10.57$ ) these indicators were 2 (1-4) years and 2 (1-3) courses, respectively. Group 3 patients (mean age $58.33 \pm 6.17$ ) had $2(1-3)$ years of an underlying disease and received 2 
(1-3) courses of CT. There were no statistically significant differences between the indicators, which makes it possible to compare these groups and eliminate the influence of potential confounders.

The M-response amplitudes in treatment groups 1 and 2 were below the normal range $(3-5 \mathrm{mV})$ and were in group 1: MEDBsin - 3.01 (2.48-3.19) mV, MEDBdex - 3.12 (2.623.53) mV, MAHsin - 3.25 (2.49-4.52) mV, MAHdex - 3.57 (2.49-4.91) $\mathrm{mV}$, and group 2: MEDBsin - 3.12 (2.23-3.56) $\mathrm{mV}$, MEDBdex - 3.12 (2.47-3.65) mV, MAHsin - 3.24 (2.45-4.12) mV, MAHdex - 3.23 (2.48-3.95) mV. In group 3 the indicators were below the norm and were determined at the following level: MEDBsin - $2.83(1.4-3.13) \mathrm{mV}$, MEDBdex - 2.86 (1.49-3.11) mV, MAHsin - 2.57 (1.13.11) mV, MAHdex - 2.75 (1.3-3.41) $\mathrm{mV}$. There were not found statistically significant differences between groups 1 and 2. A significant decrease in MAHsin in group 3 was noticed by $21.9 \%$ compared to group 1 and by $20.8 \%$ to group 2, as well as MAHdex decreased by $23 \%$ and $14.9 \%$, respectively. The study of the amplitude of the M-response after the appointment of $\alpha$ - lipoic acid in all groups was within the normal values, namely in group 1: MEDBsin - 3.08 (2.56-3.47) mV , MEDBdex - 3.39 (2.88-3.91) mV, MAHsin - 3.39 (2.91-4.68) mV, MAHdex - 3.61 (2.98$5.01) \mathrm{mV}$, in the group 2: MEDBsin - $3.38(2.84-3.89) \mathrm{mV}$, MEDBdex - 3.29 (2.79-3.87) mV, MAHsin - 3.61 (2.944.48) mV, MAHdex - 3.45 (2.93-4.12) $\mathrm{mV}$, and in group 3: MEDBsin - 3.24 (2.57-3.91) mV, MEDBdex - 3.3 (2.553.96 ) mV, MAHsin - 3.07 (2.51-3.98) mV, MAHdex - 3.37 (2.68-4.06) $\mathrm{mV}$. Significant increases were observed in all groups and, as a consequence, their rise to normal in group 3 after treatment. There was not detected a statistically significant difference between the groups after treatment. These changes are presented in figure 1.

Velocity of motor excitation on motor fibers before treatment was within the normal range $(40-60 \mathrm{~m} / \mathrm{s})$ in all groups, namely group 1: VEDBsin - $50.87(48.84-52.11) \mathrm{m} / \mathrm{s}$, VEDBdex - 50.61 (48.0-53.41) m/s, VAHsin - 51.12 (45.33$52.5) \mathrm{m} / \mathrm{s}$, VAHdex - $52.25(49.28-53.13) \mathrm{m} / \mathrm{s}$; in group 2: VEDBsin - 52.14 (48.3-57.12) $\mathrm{m} / \mathrm{s}$, VEDBdex - 53.21 (46.14-57.15) m/s , VAHsin - $52.12(48.69-58.32) \mathrm{m} / \mathrm{s}$, VAHdex - $51.32(47.13-56.46) \mathrm{m} / \mathrm{s}$; in group 3: VEDBsin - 42.03 (40.23-46.48) m/s , VEDBdex - 42.65 ( 40.8-47.0) $\mathrm{m} / \mathrm{s}$, VAHsin - $43.45(40.38-47.4) \mathrm{m} / \mathrm{s}$, VAHdex - 41.8 $(39.23-47.65) \mathrm{m} / \mathrm{s}$. There was a significant decrease in indicators in group 3 compared to group 1 and group 2 of VEDBsin by $17.4 \%$ and $19.4 \%$, VEDBdex by $15.7 \%$ and $19.8 \%$, VAHsin by $15 \%$ and $16.6 \%$ and VAHdex by $20 \%$ and $18.6 \%$, respectively in figure 2 .

The determination rate of the excitation by motor fibers after treatment revealed a decrease in the values within the normal values for all groups and their significant increase compared with the initial level, namely in group 1: VEDBsin - 51.45 (49.58-52.63) m / s, VEDBdex - 51.65 (49.85-53.58) m / s, VAHsin - 51.25 (46.72-53.1) m/s, VAHdex - $52.65(49.73-54.13) \mathrm{m} / \mathrm{s}$; in group 2: VEDBsin - 52.3 (47.3-57.1) m/s, VEDBdex - 53.5 (46.8-57.9) m/s, VAHsin - $53.1(48.9-58.9) \mathrm{m} / \mathrm{s}$, VAHdex - $51.8(47.9-57.6) \mathrm{m} / \mathrm{s}$; in group 3: VEDBsin - $45.1(41.58-49.3) \mathrm{m} / \mathrm{s}$, VEDBdex $45.05(43.2-49.55) \mathrm{m} / \mathrm{s}$, VAHsin - $47.55(43.1-49.58) \mathrm{m} / \mathrm{s}$, VAHdex - $46.52(43.8-49.85) \mathrm{m} / \mathrm{s}$. Statistically significant differences in these indicators between groups 1 and 2 after treatment were detected, but in group 3 is revealed a decrease of VEDBsin to $17.2 \%$ and $13.8 \%$, VEDBdex to $12.8 \%$ and $15.8 \%$ compared to groups 1 and 2 , respectively, and VAHsin to $10.5 \%$ and VAHdex by $10.2 \%$ in respect to group 1 , as it is shown in figure 3 .

The rate of excitation of sensory fibers before treatment in groups 1 and 2 was within the mean values $(50-60 \mathrm{~m} / \mathrm{s})$ and was in group 1: VSFsin $-55.63 \pm 9.1 \mathrm{~m} / \mathrm{s}$, VSFdex $-54.12 \pm$ $7.87 \mathrm{~m} / \mathrm{s}$, VCsin $-52.11 \pm 6.92 \mathrm{~m} / \mathrm{s}$, VCdex $-52.55 \pm 7.46$ $\mathrm{m} / \mathrm{s}$, and in group 2: VSFsin $-53.34 \pm 6.9 \mathrm{~m} / \mathrm{s}$, VSFdex $52.96 \pm 6.74 \mathrm{~m} / \mathrm{s}$, VCsin $-53.26 \pm 5.82 \mathrm{~m} / \mathrm{s}$, VCdex -53.47 $\pm 6.39 \mathrm{~m} / \mathrm{s}$. In group 3 the indicator was reduced inrelation to the norm: VSFsin $-31.96 \pm 11.14 \mathrm{~m} / \mathrm{s}$, VSFdex -31.98 $\pm 10.06 \mathrm{~m} / \mathrm{s}$, VCsin $-32.12 \pm 11.62 \mathrm{~m} / \mathrm{s}$, VCdex -32.17 $\pm 11.05 \mathrm{~m} / \mathrm{s}$. There was a significant indicators decrease in group 3 relative to group 1 VSFsin to $42.6 \%$, VSFdex to $40.9 \%$, VCsin to $38.4 \%$, VCdex to $38.8 \%$, and group 2 VSFsin to $40.1 \%$, VSFdex to $39.6 \%$, VCsin to $39.7 \%$, VCdex to $39.8 \%$, as it is shown in figure 4 .

Measuring the speed of excitation rate of sensory fibers after treatment showed normal values in group 1: VSFsin $-55.65 \pm 9.28 \mathrm{~m} / \mathrm{s}$, VSFdex $-54.72 \pm 8.04 \mathrm{~m} / \mathrm{s}$, VCsin $-52.18 \pm 6.46 \mathrm{~m} / \mathrm{s}, \mathrm{VCdex}-53.14 \pm 7.43 \mathrm{~m} / \mathrm{s}$; and in group 2: VSFsin $-54.77 \pm 6.41 \mathrm{~m} / \mathrm{s}$, VSFdex -54.63 $\pm 5.91 \mathrm{~m} / \mathrm{s}$, VCsin $-54.19 \pm 6.12 \mathrm{~m} / \mathrm{s}$, VCdex $-54.53 \pm$ $6.39 \mathrm{~m} / \mathrm{s}$; and decreased compared to the normal values in group 3: VSFsin - $36.55 \pm 9.37 \mathrm{~m} / \mathrm{s}$, VSFdex - 37.53 $\pm 8.82 \mathrm{~m} / \mathrm{s}$, VCsin $-37.3 \pm 9.84 \mathrm{~m} / \mathrm{s}$, VCdex $-36.72 \pm$ $9.76 \mathrm{~m} / \mathrm{s}$. Statistically significant dynamics were missing among group 1, but increase of the evaluated measures was noticed in groups 2 and 3 . There was revealed the reduction in group 3 relative to groups 1 and 2 respectively: VSFsin $34.3 \%$ and $33.2 \%$, VSFdex to $31.4 \%$ and $31.3 \%$, VCsin to $28.5 \%$ and $31.2 \%$, VCdex to $30.9 \%$ and $32.7 \%$, is presented in figure 5 .

ENMG examination of the peripheral nerves of the lower extremities in patients with CML and CLL revealed a slight decrease in M-responses at normal values of the rate of conduction of excitation through sensory and motor fibers. In patients with MM, multiple lesions of peripheral nerve fibers of the lower extremities were detected, which is represented by a decrease in the M-response and the rate of excitation through sensory fibers and indicates deeper lesions, namely the axial cylinder, which requires longer treatment. The difference in the dynamics of the studied indicators indicates a different degree of PNP.

Administration of $\alpha$-lipoic acid increased the $\mathrm{M}$-response rate and the rate of excitation of motor fibers in all groups of patients. The rate of excitation through sensory fibers was improved in patients with CLL and MM. Following the use of $\alpha$-lipoic acid in the complex treatment of patients with MM ENMG, the signs of peripheral nerve fiber damage in the lower extremities were worse due to the severe initial condition, but reached a medium level. The positive effect of $\alpha$-lipoic acid can be caused 
by a decrease in oxidative stress and endothelial dysfunction in nerve vessels, and, as a consequence, an improvement in the trophism and functional state of nerve fibers.

\section{CONCLUSIONS}

ENMG signs of defeat of PNP of the lower extremities are more expressed at MM. The appointment of $\alpha$-lipoic acid in the complex treatment of PNP in patients with chronic hemoblastosis improves the functional state of the peripheral nerve fibers of the lower extremities and may be a component of pathogenetic therapy.

\section{REFERENCES}

1. Kryachok I.A. Hemoblastozy. [Hemoblastosis]. Meditsina. 2019: 474500. (in Ukrainian).

2. Lemeshonok L.S. Patofiziologicheskie aspekty gemoblastozov. Minsk: BGMU; 2019: 52. (in Russian).

3. Onkoimmunologiya, Hemoblastozy [Oncoimmunology, hemoblastoses]. Medical Immunology. 2011;13(4-5):426. (in Russian).

4. Litvitskii P.F., Zhevak T.N. Gemoblastozy. Leikozy limfoidnogo proiskhozhdeniya [Hemoblastosis. Leukemia of myeloid origin]. Issues of modern pediatrics. 2016;15(5):457-70. (in Russian).

5. Volkova M.A. Klinicheskaya onkogematologiya [Clinical oncohematology]. Rukovodstvo dlya vrachei. Meditsina. 2007: 1120. (in Russian).

6. Matlan V.L., Shparik Ya.V. Onkogematologiya. Klasifikatsiyi. Klinichni rekomendatsiyi. Rezhimi medikamentoznoyi terapiyi [Oncohematology. Clasification. Clinical recommendation. Drug treatment regimens]. Galits'ka vidavnicha spilka. 2009: 190. (in Ukrainian).

7. Kuznietsova L.P., Bogoslav T.V., Reshetilov YU.I., et al. Khvorobi krovi ta krovotvornikh organiv [Diseases of the blood and blood-forming organs]. Zaporizhzhya; 2018: 123. (in Ukrainian).

8. Novikova I.A., Khuduleva S.A. Klinicheskaya i laboratornaya hematolohiya [Clinical and laboratory hematology]. Vyshehishaya shkola. 2013: 448. (in Russian).

9. Ponomarev V.V., Zharikova A.V. Nevrologicheskie narusheniya pri onkogematologicheskikh zabolevaniyakh [Neurological disorders in oncohematological diseases]. Meditsinskie novosti. 2011;1:6-9. (in Russian).

10. Piddubna 0.0., Lytvynenko N.V. Otsinka yakosti zhittya u khvorikh na gemoblastozi zurazhennyam nervovoyi sistemi [Life quality assessment in patients with hemoblastosis with lesions of the nervous system]. Problemi ekologiyi ta meditsini. 2016;20(1-2):10-2. (in Ukrainian).

11. Zyrina G.V. 0 spektre porazheniya perifericheskoi nervnoi sistemy pri zabolevaniyakh krovi [About the spectrum of the peripheral nervous system disorders in the blood diseases]. Klinicheskaya nevrologiya. 2010;4:13-6. (in Russian).

12. Grisold W., Oberndorfer S., Windebank A.J. Chemotherapy and polyneuropathies. European Association of NeuroOncology Magazine. 2012;2(1):25-36.

13. Argyriou A.A., Kyritsis A.P., Makatsoris T, Kalofonos H.P. Chemotherapyinduced peripheral neuropathy in adults: a comprehensive update of the literature. Cancer Manag Res. 2014;6:135-47.

14. Sitkali I.V., Chirichkin A.S., Kolokolov O.V. Porazhenie perifericheskoi nervnoi sistemy, assotsiirovannoe s priemom lekarstvennykh sredstv [Peripheral nervous system damage associated with taking medication]. Lechashchii vrach. 2019;5:19-25. (in Russian).
15. Koroleva E.S., Alifirova V.M., Gol'dberg V.E., et al. Klinicheskoe, neirofiziologicheskoe i immunologicheskoe obsledovanie onkologicheskikh patsientov s porazheniem perifericheskikh nervov [Clinical, neurophysiological and immunological examination of cancer patients with peripheral nerve damage]. Byuleten Sibirskoy Meditsiny. 2013;12(5):39-45. (in Russian).

16. Yakovlev A.A., Yakovleva M.V. Klinicheskie osobennosti perifericheskoi neiropatii pri paraproteinemicheskikh gemoblastozakh [Clinical features of peripheral neuropathy in paraproteinemic hemoblastoses]. Zhurnal nevrologii i psikhiatrii im.S.S.Korsakova, 2014.-N 10.-S.5-8. (in Russian).

17. Ippolitova E.G., Verkhozina T.K. Ehlektrofiziologicheskie podkhody v diagnostike i lechenii zabolevanii perifericheskoi nervnoi sistemy [Electrophysiological approaches in the diagnosis and treatment of peripheral nervous system deseases]. Acta Biomedica Scientifica. 2013;1(89):186-9. (in Russian).

18. Komyagina I.V., Belyakov K.M. Osobennosti klinikoehlektroneiromiograficheskoi kartiny i rezul'tatov ul'trazvukovogo issledovaniya perifericheskikh nervov pri polinevropatiyakh [Features of the clinical-electroneuromyographic picture and the results of ultrasound examination of peripheral nerves in polyneuropathies]. Zdorov'e i obrazovanie v XXI veke. 2013;15(1-4):1-3. (in Russian).

19. Grigor'eva V.N., Stamo A.P., Avdonina YU.D. et al. Osobennosti porazheniya perifericheskoi nervnoi sistemy pri mnozhestvennoi mielome [Peripheral nervous system damage features in multiple myeloma]. Nevrologicheskii zhurnal. 2013;18(2):4-10. (in Russian).

The article is a fragment of the research "Clinical and pathogenetic optimization of diagnosis, prognosis, treatment and prevention of the nervous system complications disorders and neurological disorders in somatic pathology" (State registration number 0116U004190)

\section{ORCID and contributorship:}

Oleksandra O. Piddubna - 0000-0002-6468-5251 A, B, C,D

Nataliya V. Lytvynenko - 0000-0002-4889-3608 B, E, F

Anzhelina M.Krivchun - 0000-0003-2775-2029 ${ }^{B, E}$

Kateryna A.Taryanyk - 0000-0003-4606-5398 B, E, F

\section{Conflict of interest:}

The Authors declare no conflict of interest.

\section{CORRESPONDING AUTHOR Oleksandra 0. Piddubna \\ Ukrainian Medical Dental Academy \\ 23 Shevchenko St., 36000 Poltava, Ukraine \\ tel: +380954633153 \\ e-mail:alexaneurolog@gmail.com}

Received: 09.04 .2020

Accepted: 27.07 .2020

A - Work concept and design, B - Data collection and analysis, C - Responsibility for statistical analysis,

D-Writing the article, $\mathbf{E}$-Critical review, $\mathbf{F}$ - Final approval of the article 